\title{
Non-institutionalised Lay Religious Communities in the Czech Republic and the Care for the Ill Strategy
}

\author{
Jan Váně \\ ${ }^{1}$ Department of Sociology, Faculty of Philosophy and Arts, University of West Bohemia, Czech Republic \\ Correspondence: Jan Váně, Department of Sociology, Faculty of Philosophy and Arts, University of West \\ Bohemia, Avalon, Poděbradova 1, 30614 Plzen, Czech Republic. E-mail: vanejan@kss.zcu.cz
}

Received: January 10, 2013 Accepted: February 25, 2013 Available online: February 22, 2013

doi:10.11114/ijsss.v1i1.74

URL: http://dx.doi.org/10.11114/ijsss.v1i1.74

This study is supported by the "Institutional support for long-term development of organization - Department of Sociology - UWB” grant.

\begin{abstract}
The objective of this study is to focus on how two non-institutionalised lay religious communities in the Czech Republic, selected for this research, apply an adaptation strategy called the care for the ill strategy. The aim is to demonstrate the way these communities view the phenomenon of health/illness and how it is reflected in their relationship to the Catholic Church. This paper is part of a larger ethnographic study that analyses activities carried out by non-institutionalised religious communities active in the Catholic environment.
\end{abstract}

Keywords: Catholic Church in the Czech Republic, non-institutionalised communities, care for the ill strategy

\section{Introduction}

Jose Casanova, a scholar working in the field of sociology of religion, has pointed out that in late modern societies religion has vacated the private sphere to which it had been confined earlier and is now entering the undifferentiated sphere of civil society, where it is involved in the fight over the legitimacy of society, including the conflicts over the redrawing of the social boundaries that had thus far been accepted as valid. In order to illustrate the transformation of religion and its re-entry into the public sphere, Casanova abundantly uses facts gathered mainly in the Catholic environment: these have helped him to prove that the Catholic Church has again become an influential player in the socio-political arena (Casanova, 1994: 75-134 and 167-207). An interesting question, however, presents itself when we think about the Czech Republic: what kind of activities does the Catholic Church carry out in this country, notorious for the indifference of its citizens to religion?

To a certain extent, this question can be answered with a finding I formulated on the basis of data gathered through a case study that formed part of a larger research project targeting non-institutionalised religious communities active in the Catholic environment and their activities. For this reason I have concentrated mainly on the following question: how do these communities incorporate the issue of health in their agendas? Today, in a society with a lukewarm relationship to religion health represents a new type of the sacred. For this reason the links between health, religiosity and the way religious groups act on the public represent an interesting issue to explore. ${ }^{1}$

I would firstly like to describe the position of the Catholic Church in the Czech Republic. Then I will conceptualise the term non-institutionalised religious communities. Having done this, I shall outline the results of the ethnographic research. ${ }^{2}$

\footnotetext{
${ }^{1}$ Sociology of medicine points out that in late modern society health has become the central point of interest, turning at the same time into a consumer product and life style (see Nettleton, 2006: 33-35).

2 This ethnographic research was based on the assumption that running a community or joining one represents a significant biographical event and that studying this stage of a person's life helps provide an understanding of the metamorphosis of values, behaviour and interpretations in response both to processes inherent to the modern era and vehicles of modernisation processes. By describing strategies, I hope to help explain how actors perceive their community, the Church and modern times and how their perception has been repeatedly reassessed during the process of the building of the community. In order to to this, I have chosen to focus on the care for the ill strategy.
} 


\section{The Catholic Church and Its Position in the Czech Republic}

The status of the Catholic Church in the Czech Republic is quite interesting and there are a number of reasons for this. To begin with, it must be noted that the level of religiosity in the Czech Republic is much lower than in the rest of Europe. Findings from almost every research project have shown that affiliation or non-affilication with a Church is a differentiating principle among the Czech population (it governs the individual value frameworks on which perceptions of the world, life, society and normative systems are based) (Pickel \& Sammet, 2012).

\begin{tabular}{|c|c|c|}
\hline \multirow[b]{2}{*}{$\begin{array}{l}\text { Religious affiliation (claims to belong to } \\
\text { a Church or a religious group) [1] }\end{array}$} & Czech Republic 2001 & Czech Republic 2011 \\
\hline & $32 \%$ & $14 \%[2]$ \\
\hline Roman Catholic & $83 \%$ & $74 \%$ \\
\hline No religion & $59 \%$ & $34 \%$ \\
\hline No answer & $9 \%$ & $45 \%$ \\
\hline N (total population) & $10,230,060$ & $10,562,214$ \\
\hline
\end{tabular}

Source: Czech Republic Censuses 2001, 2011

[1] In 2001, the number of religious people include even people who claimed not to belong to a concrete Church.

[2] In 2011, 14\% of the population claimed to belong to a Church or to a religious group, while $7 \%$ of the population said they were religious but did not belong to

a Church or to a religious group. This means that, if methodology had not change, $21 \%$ would be the figure in this category in 2011.

Table 1. Population and Housing 2001, 2011

According to data from 2011 Population and Housing Census, only 21\% of the total population see themselves as religious people. However, of this $21 \%$, only $14 \%$ declare themselves to be followers of a Church or another religious organisation. Most (74\%) of the $14 \%$ of religious people who claimed to be members of a particular religious organisation are Roman Catholics. This $74 \%$ represents approximately $10 \%$ of the total population. By contrast, $34 \%$ of respondents stated that they have no religious faith. In absolute numbers this $34 \%$ represents $3,612,804$ people out of the total population of $10,562,214$. Yet the largest part of respondents ( $45 \%$ of the population or 4,774,323 people) left the question about faith unanswered. From the above it is apparent that Roman Catholics make up the largest religious minority in the Czech Republic. This, on the one hand, makes the Catholic Church a powerful institution, formally disposing of $10 \%$ of the voices in the population, on which it can rely in political and cultural disputes with the majority society. On the other hand, however, various research projects have shown that in the eyes of the wider public, the Church does not exercise the level of influence that would correspond to its cultural and historical significance.

When we look at the issue of trust in the Church from a long-term perspective, we see that Czech society has always ranked among countries with the lowest levels of religiosity ${ }^{3}$ and that since the middle of the 1990s the level of religiosity has remained stable at an average of one-third of the population. In general, however, when it comes to existential questions and various moral dilemmas, the Church is seen as a less significant actor. And the downward trend continues: society expects less and less from the Church and the only field in which it is still expected to play an important (service) role is the sphere of social services (Prudký, 2005: 55-56).

${ }^{3}$ Cf., for example Standard \& Special Eurobarometr. http://zacat.gesis.org [quoted as of 12/12/ 2012]. 
The Church sees the continued distrust the majority society shows towards it as an effect of systematic communist propaganda and of the negative picture painted of the Church by the media. According to the Church itself, this leads to a situation where it is seen as an institution trying to assert its ideology and its own goals without taking into consideration public well-being.

Feelings of distance towards and scepticism of the Catholic Church mainly gained strength during the period of communist rule. But the real roots of mistrust and uncertainty about the Catholic Church lie in the distant past. ${ }^{4}$ One good example of this is a disagreement that arose between T. G. Masaryk (the Republic's first president) and J. Pekar (an eminent historian) over what role the Catholic Church played and what kind of influence it had on the foundation of the First Czechoslovak Republic in 1918. ${ }^{5}$ During the process of building the First Republic, the Church was seen as one of the governing institutions of power in former Austria-Hungary and as such, the new State regarded it with reservations.

The rise of communism brought yet another change to the position of the Church, as it soon became a centre of resistance to the totalitarian regime. Some Church representatives, however, joined the conformist and pro-regime organisation Pacem in Terris. ${ }^{6}$

The pressure exerted on believers by the regime and the repression of the Church by the communists had a strong impact: the Church today is very cautious when formulating opinions on the majority society and is unwilling to set the agenda for discussion in the public space. ${ }^{7}$ This means, among other things, that no effort is made to influence public opinion and that the Church has largely adopted a wait-and-see attitude. This inability to adopt a strong viewpoint is further aggravated by the hesitant and ambiguous way in which the Church deals with its internal problems: it has not yet been able to fully come to terms with the legacy of priests collaborating with the communist regime, to settle its economic affairs in a satisfactory way, or to bring an end to affairs related to the unacceptable sexual behaviour of some priests (Prudky, 2005: 7-11).

The Church is convinced that this negative picture has been enhanced by the growing influence of information technologies, which have so empowered the media that they have begun to claim the right to fulfill basic human needs, including religious ones. The Church sees this as an unacceptable trend, eroding the influence of traditional institutions, such as the family, education, and the Church itself.

Aspiring to reverset the way it is seen by the public opinion in the Czech Republic, the Church has been explicitly encouraging its members to actively revolt against (in its opinion) the hostile media and majority society. This active revolt, however, is not perceived as a refusal or negation of the majority society, but rather as an effort to create a space conducive to a pluralistic way of thinking. When it comes to the strategy to adopt in order to do this, the Church believes in the formation of alliances with kindred spirits (people and institutions). For this reason it has strived to draw the public's attention to civil society and to being active in the public space, emphasising at the same time the need to work for as broad a community as possible. ${ }^{8}$

This endeavour to turn opinons around is supposed to be carried out by so-called well-formed laypeople, or, eventually, lay religious communities and movements, which, in the second half of the 20th century, have again become very active: ${ }^{9}$ their ascension and growing influence since the Second Vatican Council has forced the Church to take them seriously. ${ }^{10}$ In order to stick to the subject of the study and the research questions as closely

${ }^{4}$ For more details on the attitudes of Czech society to religion and to the Catholic Church (see Lužný \& Navrátilová, 2001: 85-98 or Václavík, 2010).

${ }^{5}$ President Masaryk saw the high point of Czech history in the Hussite movement and in the religious group called the Unity of the Brethren, while J. Pekar thought that the highlights and cornerstones of Czech identity historically lay in the era of King Charles IV and in the activities carried out by the Catholic Church. Comp. Havelka (1995).

${ }^{6}$ For details on the position of the Catholic Church during the communist era (see Balík \& Hanuš, 2007).

${ }^{7}$ For details on agenda setting by the Czech Catholic Church (comp. Váně \& Kalvas 2011: 30-49).

8 Peace and Good Pastoral Lettre. A Christian Greeting to the Beginning of the $21^{\text {st }}$ Century. 2000. Prague: Czech Bishops Conference [Quote 12/4/2011], [on-line]. <http://tisk.cirkev.cz/res/data/004/000526.pdf?seek=1151404189>.

${ }^{9}$ Within the Christifideles exhortation, the Church encourages lay communities and movements to become involved in fields such es environmentalism (ChL 42), health, the pro-life movement (ChL 38), freedom of confession, protection of the poor and their human dignity as well as economic self-sufficiency (ChL 47, 48, 53), etc.

10 The position of laypeople within the Church was addressed as early as by the Second Vatican Council, particularly in the Apostolicam Actuositatem decree (Second Vatican Council Documents - Dokumenty II. vatikánského koncilu, 2002: 379-413), but in the 80s, it became evident that the dynamics of socio-cultural changes require a greater effort when it comes 
as possible, I have chosen to explore the so-called new communities.

\section{Non-institutionalised Lay Religious Communities: What Are They?}

It has become evident that a growing number of people active within the Church have been multiplying their efforts to respond to the socio-cultural pressures of late modernism and to questions of faith. This has given rise to an interesting phenomenon: active non-institutionalised lay religious communities (NLRC) are forming within the frame of the Catholic Church even in the highly secularised Czech Republic.

What are the NLRCs? I shall now explain how I constructed their definition for the purpose of this text. My prerequisite is that no generally accepted definition of community exists and that the very nature of community is that it is conceived as such by social actors living within it. In order to grasp the phenomenon of NLRCS, I worked with the following concept of community: a community is a form of co-existence that features strong personal and emotional ties among its members. Interactions within a community are not possible unless shared (moral and social) values and norms are accepted. Members of the community have a personal interest in seeing the community function properly. All this means that a community is quite a small social unit bound together by a common goal, norms and strategies. Its everyday activities and field of action are confined to concrete borders and its ontological status derives from the sense of its own 'specificity' which, in turn, is defined by the intensity of 'protest' against selected mechanisms of late modern society (König, 1968).

The foundation of the Gofer ${ }^{11}$ and Zahrada ${ }^{12}$ (Garden) communities can be seen as a result of the need to face a double challenge: on the one hand, these communities refuse to accept the ever-rising isolation and uncertainty of individual existence, which they see as a manifestation of mass society and which, according to them, is related to individualisation, pluralisation and the ever-stronger trend towards consumerism that distorts what they deem a desirable way of life (including authentic religious experiences). On the other hand, they have adopted a critical stance towards institutionalised religion, represented in this case by the Catholic Church. As an alternative to it, they offer a specific form of life in a circle of spiritually affiliated people.

These communities originated in the Catholic environment and they acknowledge this. They are reserved for laypeople only. This approach contrasts with other movements and mixed communities active within the framework of the Church (such as the Focolare Movement, Cursillo de Cristiandad, the Schoenstatt Movement, Koinonia Giovanni Baptista or the Chemin Neuf community in Tuchoměrice near Prague) that are open to clerics, too.

The greatest obstacle to defining 'non-institutionalised lay religious communities', however, lies with the term non-institutionalised. This is because, from a sociological point of view, they are institutionalised, meeting three basic conditions: during their existence (1) formal norms are created, endorsed and (2) internalised by their members and (3) formal and informal sanctions are also defined. These norms and sanctions are agreed on and are binding for all members of these communities. Despite the fact that both of the communities examined in this study have only existed for a relatively short time, their sets of rules have already reached the stage of 'consolidation'.

to thinking through the position of laypeople within the Church. For more information on the lay movement and its influence in the Church, (see von Balthasar. 2004).

11 The number of regular members of the Gofer community fluctuates, with a maximum number of 6 adults. The community is a home for men and women between the ages of 28 and 45 and for the children of married couples. The majority of the members belong to the same generation. The majority of permanent members of the community come from towns with more than 30,000 inhabitants. When the community was created, most of the founders were generational peers between the ages of 20 and 35. In addition, there are also so-called affiliated members who cooperate with the community but who are not physically present in the community (while they are still members of the association). Some of these people were members of the original fellowship from the 1990s, but for various reasons were not able to take part in the transition from the desire to live a community life to actually living a community life. There are 26 of these affiliated members. Members of the community have jobs outside the community, and on top of this they try to participate in the community's programme, which involves working with young people in the region, and trying to help them find authentic forms of life that are not necessarily devoid of spiritual or, in fact, religious aspects. Last but not least, the goal is to turn the community into a spiritual and cultural centre in the region.

12 There are 12 regular members of the Garden community (i.e. members of the association). The idea of creating a community therapeutic centre has been gradually abandoned and for this reason not all the members of the association participate in running the centre as it functions today. The therapeutic centre has approximately 19 employees who participate in its activities on a daily basis. The key members of the community and its founders are between the ages of 40 and 45 . 
But these communities can also be perceived as non-institutionalised in the sense that they are not subordinate to the Church in any legal standpoint (which is the case of the other movements and groups I mentioned above) and that the Church does not does not wholly accept them. Both of the targeted communities, however, do strive, to a certain extent at least, to fulfill and carry out the goals they have in common with the Catholic Church and that come under its jurisdiction, such as pastoral work.

Canon 214 of Canon Law recognises and defines the existence of non-institutionalised religious communities. ${ }^{13}$ It says that it is possible to found a Christian community that does not necessarily come under the jurisdiction of the Church (i.e. does not have to stick to institutionalised processes). At the same time, however, the Code of Canon Law anticipates situations in which a non-institutionalised community might become a religious, social or political problem. These situations are described in the Canon 216, which says that it is not possible to legally ban the community, but that the Church has the right to disavow it ${ }^{14}$.

Nevertheless, a community aiming to act in the public sphere requires some form of legal status. There are many reasons for this and one of them is the need to be able to raise funds and face economic pressures. The most common way to solve this problem is to found an association (this procedure is governed by Section 18 of the Civil Code). In this case, however, a community must not define its activities as religious because the Act on the Association of Citizens (Act 83/1990, Section 1, art. 3) states that it does not apply to churches and religious communities. The activities of churches and religious communities are governed by the Act 3/2002 Coll. If a community, however, wishes to be governed by this law it must become an independent religious subject. This means in fact that the given (Catholic) community must disassociate itself from the Catholic Church, which in the case of the communities in our study is something they do not want to do. The communities under observation have chosen to function in compliance with the Act on the Association of Citizens and are, therefore, considered by law to be institutionalised communities that must define their activities on a non-religious basis. The Church, on the other hand, sees these communities as non-institutionalised groups. And this perspective determines the angle of view adopted in this paper, which talks about non-institutionalised lay religious communities.

\section{Communities: Foundation and Adaptation Strategies - Context}

The two communities (Gofer, Garden) under observation developed in steps over the course of the 1990s. My first contact with the members of the Garden community dates back to 2002 (Gofer 2006). I started meeting key representatives of both communities and used the snow-ball technique to enter into contact with other members, the so-called affiliated members and supporters. My principal source of data was participant observation carried out between 2008 and 2011. ${ }^{15}$

The data were made available through an ethnographic field research project in which I concentrated on the position of the Czech Catholic Church and on non-institutionalised lay religious communities (NLRC) originating within the framework of the Church and reacting, in a specific way, to processes currently going on in the society. I have chosen two communities, Gofer and the Garden, and studied what means they have been using to create such forms of living that would represent an alternative to trends usually associated to late modern societies. I have researched the way particular NLRC think about modernisation processes, how they define themselves in opposition to them and what relation they have to institutions that might be seen as the vehicles of these processes, the Church being the principal one in this case. I have also looked at strategies communities have chosen in order to carry out their plans and at the way the Church works with a set of strategies that ought to help it put in practice its goals and targets in a deprivatised society. I was wondering whether the Church has developed strategies that would allow it to set issues on the agenda of a society that is prevalently secular or indifferent to religion and to bring the public's attention to itself. I also explored what role the NLRC play in this process and have also been interested in the adaptation strategies the researched communities have decided to apply.

A general conclusion is that the researched communities have some characteristics in common: both were

\footnotetext{
13 'Christians have the right to found and manage associations of a charitative character or to worship or to support the Christian calling in the world and to gather in order to reach the above mentioned goals.' (Kodex kanonického práva, 1994: 89).

14 "All Christians participate in the mission of the Church and taht is why they have the right to act and support the apostolat; no activity can be called Catholic unless it is approved by relevant Church authority”. Ibid., 89.

15 The methodology defines two extreme positions: 'total observer' vs. 'total participant' (see Denzin \& Lincoln, 2005: 217-233).
} 
founded by people who wanted: (1) to share their longing for a feeling of unity and a shared life, ${ }^{16}$ (2) to experience the radicalism of Christianity ${ }^{17}$ and (3) to cut their ties with the urban environment. ${ }^{18}$. Characteristics (1) and (3) were later emphasised and represent the reason why new members and sympathisers kept flowing into the communities. The dream of a community in the early 90s, however, was not based on the idea of a return to early Christian communities in the sense of a return to fundamental authenticity. It was rather an attempt to transform, or, eventually, tame the influences of modernity, such as consumerism and egoism, i.e. processes that could be seen as a normative model of individualisation in the newly developing Czech society. The members of the communities, in other words, were looking for possibilities to enter the public space and actively declare their belonging to Christianity (or, eventually Catholicism) and striving to carry on with their spiritual development.

Another shared characteristic of the two communities is the age of their founding members, who belong to the same age group. Besides age, they also share similar life experiences (such as conversion or primary socialisation within the environment of the anti-communist dissent). The people in these peer groups were, at the time the communities were founded at the end of the millennium, between the ages of twenty-five and thirty. The founders of both groups, too, were looking for inspiration outside the Czech Republic: this stems from the fact that, before 1989, this kind of co-existence was unknown. It was therefore Delrow House ${ }^{19}$ therapeutic community (see also the Camphill movement ${ }^{20}$ ), and the House of the Open Door Community ${ }^{21}$ that became important sources of inspiration.

Inspiration and ideas are important, of course, but so too is the need to survive. The journey from the dream of a community to actually founding one is often very long and success is uncertain. Adaptation strategies help communities face economic pressures and, at the same time, provide them with the means to win recognition from the outside world. They also help to make it clear where the community is going and what its values are, and to outline possibilities of future development. Both of the two communities under observation adopted three elementary adaptation strategies, each of which was accentuated in a different period of the community's development. The intensity with which these strategies were used also varied according to what stage in development they were used. An important feature of these strategies is that at the beginning of the existence of the community, they were not necessarily well (and rationally) thought through. The three strategies were:

(1) the environmentally-motivated behaviour strategy ${ }^{22}$

(2) the being different and religiously un-orthodox strategy ${ }^{23}$

\footnotetext{
16 'The most important thing is that we (...) have come to share a roof, we have joined those who desire to live together and live a profound life. It is important that we want to create relationships that allow us to really feel that we belong somewhere and that we are connected to others and that help us reach our goal, which is to really be now, at this moment (...) and each of us desires to be able, in this community, to fulfill our calling and the calling of the community as a whole.' (Member of the Gofer community)

17 'The idea was to really share life with disabled people, (...) in a community; to make it clear that we take Christianity seriously.'(Member of the Garden community)

18 'The trick is to live a normal Christian life and I think that a normal Christian life is simply prayer, community, unity in diversity and some kind of service. And I think that for people who live a common life somewhere in town, in the diaspora the Christian diaspora for example - it is so hard to create the conditions to do this in that it is virtually impossible, isn't it? People are usually just glad to get to know each other and to get to see each other from time to time. I think that there are options for young people, that they have some means for socialising. But when people become adults, this doesn't work anymore. I don't see this as a useful tactic, not at all, this was too little for me, I needed to take this somewhat radical step because I wanted to live what I consider to be a normal Christian existence.' (Member of the Gofer community).

19 http://www.wzimmermann.flyer.co.uk/delrow/ [quote 12/12/2012].

${ }^{20}$ http://www.camphill.cz/ [quote 12/12/ 2012].

${ }^{21}$ Cf. <http://www.houseoftheopendoor.org/> [quote 12/12/2012].

${ }^{22}$ The environmentally-motivated behaviour strategy is the most apparent, being manifested by acts such as moving to the country, embarking on animal husbandry or using natural products in frame of therapeutic activities (Garden). Another example of the emphasize communities put on the environmental aspect might be meetings organised in the premises of the Gofer community during which a lot of space is reserved to discussions about themes such as landscape architecture. The Gofer community as a whole concentrates, in fact, on the problems related to landscape memory, its revival and on prevention of landscape devastation. It also organises awareness campaigns incorporating traditional craft courses, etc. The Garden community, in turn, uses traditional technologies to make products such as textiles, candles, bread, beer, etc.).

${ }^{23}$ Both communities have to cope with the fact that their existence is stained by distrust or indifference the mainstream
} 
(3) the care for the ill strategy

\section{The Care for the Ill Strategy}

I shall now turn to the third strategy type, which was adopted by both of communities under observation, i.e. the care for the ill strategy. Communities conceive illness as an important theme around which they concentrate their activities and form their goals. In the case of the Garden community, the theme of illness was present in the minds and plans of the founders from the very beginning. They perceived the care for people with mental disorders as a manifestation of the radicalism of Christianity and this orientation also matched their personal preferences. ${ }^{24}$ Inspired by the Camphill communities, they thus founded a family-type residential community, housing both people 'normally' adapted to the general social environment and those who suffer from some kind of health (i.e. diagnosed) disability, including them in helping to run the community (therapists, assistants, etc.).

The care for the ill strategy thus helps to launch a community made up of a group of volunteers trying to live the idea of a fellowship that unites two worlds: that of healthy people and that of those diagnosed or stigmatised as ill by the majority society. At the same time, the care for the ill strategy made it possible for the community to be granted legal personality. And, on the top of the above, this strategy corresponds in fact to the Church's agenda of caring for the weak and excluded. In addition, social work (such as charity and care for ill or elderly citizens, etc.) is the area most often perceived by Czech majority society as the one in which the Church ought to be engaged and that is somehow the reserve of the Church, so its involvement in this area is not viewed as a problem. The Garden community is distinct in terms of how it applies the illness strategy and in small details relating to how it actually cares for the ill. The strategy was internalised and developed in a way that started to influence the idea of how the community should be run. The initial plan to run a family-type residential community that is home to married couples and their children as well as to people suffering from various medical disabilities (and to assistants) has gradually been reevaluated. The care for the ill strategy, however, has remained the central idea of the Garden community, structuring all its aims and activities, as well as its very purpose.

As already noted, the Garden community chose to concentrate on the issue of health and illness from the very beginning. This was not the case of the Gofer community, which did not internalise this issue until later: it did not adopt the care for the ill strategy until it was forced to reconsider its aims and purpose. From that moment, a clear shift can be seen in the way selected adaptation strategies are applied.

Unlike in the Garden community, in the Gofer community the care for the ill strategy is not explicit in nature. The original purpose of the community was (quite generally) defined as a journey of spiritual growth, service and readiness to be available to the needy, and that somehow had to be conceived in concrete form.

I think that at this point we have reached a state of affairs where we realise that this strategy needs to be developed, that we need to seize it somehow instead of just letting it go and hoping everything will be all right. That we need to start doing things somehow professionally and take care of the community from an economic point view as well, to make sure we can sustain it.

(Member of the Gofer community)

The quote shows that the Gofer community did not start to work with thecare for the ill strategy until it had already existed for several years, as soon as its existence (membership and housing) had become stable. The adoption of this strategy not only reflects an ideological shift but is also a way of defusing internal tensions over

society feels toward the Church. Communities, however, need to bring the mainstream society's attention to them since they need to inspire it to help them carry out their goals. One of the important aspects of this need is, of course, the necessity to sustain the community economically. By "being different", then, I understand the ways communities present themselves to the public while trying to do this in a saliently distinct manner that would allow them to be clearly distinguished from the Church. In frame of this effort, they started to organize events that might now be seen as their hallmarks: these events are related exclusively to the community and they have gained, in the course of the time, a great symbolic value, some people considering it a question of prestige to participate. What are these events? There is quite a wide range of them, music and theatre festivals being the most visible and accessible. There are also workshops organised with the aim of to promote craftsmanship. All year long, shorter (1 day) or longer (weekly) work stays are organized: during these stays, visitors are given a chance to experience the everyday routine of physical work and contemplation oriented on experiencing the present. And, last but not least, communities organise lecture and seminar cycles targeting a very wide range of social science-related themes to which they invite various guests: the characteristic feature of these events is that guest speakers often present opinions that are not quite in line with the official standpoint of the Church.

24 'All of a sudden, I had the feeling that I was looking for something deeply social, that I wanted to do social work, really live with disabled people. That this is one of the important features of what serious Christianity means, that it is the sincerity of life itself.” (Member of the Garden community) 
the extent to which the community ought to be open to the external world. The original plan, put in practice during the first couple of years, was (1) to share life with anyone who comes from the outside, the main objects of this sharing being the countryside, the garden, the house, and work and time in general (all of this being implicitly or explicitly framed by communitarian religiosity), and (2), to organise events aimed at offering space for an alternative way of studying, celebrating, working and resting. Gradually, a third aspect of the plan developed: to provide people from the outside with the means to recreate their energy through a programme of accompaniment (by a member of the community) (3). The third aspect of the plan is, in fact, nothing other than the adoption of the care for the ill strategy.

When a child needs some form of treatment, then they spend some time in a sanatorium, for example. And, well, when an adult wants to recuperate - or recreate, as we say in Czech, this is a beautiful word, isn't it, re-create - they go to a spa, for example. Well, and when you want to do something like this for yourself, for the entire self I mean, when you need to recuperate or you just simply want to rest, you are welcome to come to us. It is simple - when you feel that you are unable to carry on (...) you come to us and this is what we offer to you.“

(Member of the Gofer community)

While the Garden community concentrates on people diagnosed with mental disorders and cooperates with medical experts, Gofer focuses on another contemporary problem: the ever-spreading feeling of being overwhelmed, of burnout or frustration, that growing numbers of people are suffering from. The community is addressing this issue by offering a special 'package' to anyone interested: stays from several days up to three weeks, and structuring the time and activities of members in a different way than what is common in late modern society. ${ }^{25}$ The language of medicine is used to describe all this.

People who come to the community with the intention of spending some time in it and finding peace of mind may, as already noted, stay for a number of days up to three weeks. How they spend their time in the community depends on their vision of their stay and on what the community offers. Usually, the types of activities provided can be divided into two general groups: spiritual (morning and evening prayer together with members of the community, studying spiritual literature, trips, contemplation) and physical (working in the garden, bread baking, wood cutting, mowing lawns, etc.).

Both types of activities are complemented by what is called spiritual companionship, provided by a member of the community. Spiritual accompaniment involves elements of psychotherapy, confession and a helping interview. It might, in fact, be seen as a form of indoctrination that makes the visitor live a reality that is characterised by feelings of community spirit and safety and by an atmosphere of listening. This, in fact, is the treatment offered to individuals who have lost their way and are trying to find rest in times when nothing is certain. Visitors not only have the right to pick the kind of work they want to do but they can also select the topic they want to discuss with spiritual companion in the community. This person takes their wishes into consideration and accordingly prepares a schedule of meetings and activities. Everything is voluntary. To give an example of the kinds of topics chosen by visitors, we can cite: problems related to the quest for meaning in life, difficult situations in which important, life-impacting decisions have to be made, problems in one's personal life or religion-related issues concerning attempts to discover one's faith/religious affiliation or the desire to live a spiritual life.

It is, however, possible to visit the community without participating in the above-mentioned activities and to use the stay as an opportunity to rest and meditate. In the case of the Gofer community, the care for the ill strategy (which can, in fact, really be seen as a health package) reflects the current trend of wellness programmes (by using the infrastructure of the community, customers buy a healthy lifestyle product). The community, in turn, gets attention and acquires a degree of economic self-sufficiency. At the same time, the care for the ill strategy gives members of the community a chance to fulfill their own goals, such as 'to live in a community' or 'to preach spirituality'. The above-mentioned activities appear to be popular and effective: they meet the growing demand for spirituality in mainstream society, and the model of a 'spiritual spa' has inspired other religious organisations within the Catholic Church (including those that are traditionally seen as strictly closed, such as the Trappists ${ }^{26}$ to come up with similar programmes.

\footnotetext{
25 'What we want to do - and I hope that I am not talking about this prematurely, we have had a couple of people with us already - (...) we want to offer some kind of continuous stay, let's say for one to three people to start with, who would live here with us for some time, following a precise rhythm of life, in which we would combine the time for prayer, spiritual assistance, manual work, and time for being alone.' (Member of the Gofer community)

${ }^{26}$ Cf., for example, http://www.novydvur.cz/cz/guests.html [quote 12/12/2012].
} 
I shall now explore possible answers to the question why communities have been turning to the care for the ill strategy. One of the reasons is that, from a strictly economic point of view, this is the most successful model for ensuring the community's economic existence. The cult of the body dominates our era: the body is the vessel of the individual's deepest identity, and today it is identified as one with the consciousness. Illness (be it of a mental or physical nature) is reacted to very sensitively (Lipovetsky, 2003: 84). At the same time, however, we have been witnessing how institutions originally created to accompany individuals through life and support them in difficult times (i.e. to protect them and make sure their rights are not violated) not only do not function properly but are often becoming the source of difficulties themselves (Beck, 2007: 47). Any offer to reduce or remove pain or promise to offer attention and a warm reception (not provided by State or medical) institutions is therefore welcomed and any subject that extends such offers is encouraged.

The tendency to seek help with caring for the ill from religious organisations and groups has been enhanced, in the Czech Republic, by historical circumstances. The communist regime pushed religion and the Church in particular out of the social services sector. Services offered to ill people by State institutions are, however, insufficient and inadequate even today (whether it be hospitals, hospices, etc.) and these institutions have been facing substantial criticism. This has helped religious groups and organisations to filter into a sphere which is anyway traditionally seen as their natural domain.

When the above is taken into consideration, it is not surprising that religious groups have been trying to expand their sphere of influence within this domain: it is even less surprising when we realise that since the start of the age of industrialisation and urbanisation, the population has ceased to seek support and help from the Church in everyday activities. Advances generated by technical progress have deprived religion of its influence on agriculture and simultaneously made it insignificant in the field of medicine. Hugh McLeod has shown how mechanisation increased the degree to which it is possible to control agricultural production, which, in turn, led, for example, to the end of praying to summon rain. Analogically, progress in medicine decreased the dependence on faith healers and saints ascribed with supernatural abilities (McLeod, 2007: 125129). Extension of life expectancy and the improvement of health care, however, did not cure everything. This means that ill people usually do not turn to those endowed with supernatural abilities, which, however, does not exclude the eventuality that they do so when they are approaching their last moments. ${ }^{27}$ When the above-mentioned is combined with the cult of health, so when it is treated as illness, there is plenty of room to explore. This assertion is even more applicable when we realise that these communities do not care solely for the social-work dimension of health care, but through health care look for new forms of spirituality that correspond to the needs of today.

The care for the ill strategy, however, puts the communities in a paradoxical situation. Their original desire was to form a community that would enable its members to live the sort of life that does not succumb to the trends of late modernity. The communities refer to themselves as parallel poleis or oases (Gofer), claiming they represent an alternative form of being and living. This applies also in the case of the Garden: its effort to create a community therapeutic center also represents an alternative to prevailing medical trends. The communities have chosen strategies that help them to put into practice a way of life that does not have to adapt to current standards. The paradox, however, lies in the fact that both communities in fact came up with a form of living and co-existence with others that later proved to be the only, or, eventually, the most demanded commodity the people around them were interested in, and one that has helped them to attain economic, status and social stability. The absurdity of the situation is that what was supposed to be a desirable form of existence has become the subject of commercialization. There are only two possible ways out of this inner trap: to accept what has happened, which then means abandoning the ideals of the community (Garden), or to reject the given state of affairs, which leads to internal pressures and conflicts (Gofer) that could lead as far as to the break-up of the community.

\section{The Care for the Ill Strategy and the Relationship between the Lay Communities and the Church}

The relationship between the Church and the non-institutionalised lay religious communities in this study is complicated. The Church expects that communities become a source of well-formed laypeople who can actively enter the public space and put Church-related themes on the agenda. These expectations are not entirely false. But the communities do not wholly share the Church's view. The most striking conflict can be seen on the administrative level. The communities under observation have different ideas about the competencies attached to their domain of activity than the Church. They also have to react to the expectations or distrust of State

${ }^{27}$ If we leave aside the most famous place for the ill (Lourdes), we can cite as an example in the Czech context a Catholic priest named František Ferda. For more information (see Rejdák. 1994). 
institutions and organisations active in the place where they have settled. This seems to have been handled adequately, and discords have mainly occurred while the communities were trying to define their competencies in relation to the Church (to which they have to justify their existence).

The relationship between the Gofer and the Garden communities and the Church has been changing since the communities were founded. To find the term that would best describe it, we might say ambivalence. Both communities, at the very beginning, made use of their relationship with the Church. They settled in vicarages with the help of the given bishropic in the area, which eventually sold the vicarage to them. However, from the outset there were hidden problems: the Garden community, for example, turned the vicarage into a therapeutic center. In order to obtain possession of the house, however, it was initially unable to reveal its intentions to the bishopric.

We moved in, as a married couple, being told that we were allowed to live here for a year but that we had no right to start anything. Well, and that year, in fact, we spent trying to persuade the Bishop and the people around him. All year round we worked on developing a social network and started organising events for people. They [the Bishop and people around him] wanted a churchman to live here, but I knew whom they were considering and none of the two were even considering doing so. So I knew that their plan was just a front (...) well, and when we managed to get the Bishop and the people around him where we needed to have them, then it was decided that the community could be founded.

(Member of the Garden community)

The Garden community has managed to push through its plan to found a community to take care for the mentally and physically disabled despite the original intentions of the Bishopric. The Gofer community initiative, on the other hand, does not interfere with the plans the Church has for the vicarage at all: the house was in such poor condition that the Church saw the community as the last chance to save it. The most important factor, however, influencing the relationship between the Church (represented by the Bishop and the people around him) and communities is the relationship to the clerics assigned to the parishes in which the communities are active. In the case of both of them, this relationship is quite a complicated one.

The Garden community sees the local pastor as a person who was unable to help them when they needed to form good ties with the local population while settling in. On the other hand, they have not had any major problems with him and take advantage of his shyness to carry out their own plans. ${ }^{28}$ The pastor, in fact, seems to embody the Church: since he is a weak man, the community sees the Church as a weak partner, cleaving to a way of thinking and acting that was typical of communist times and unable to adapt to the needs of today. For this reason the community harbours somewhat skeptical feelings towards the Church and its ties to it have gradually been growing weaker.

Similarly, the relationship between the Gofer community and its local pastors is not very warm either. They have reduced their contact to minimum; the relationship can rather be described as a tacit lack of interest and disdain. Despite this, the Gofer community continues to declare its affiliation to the Church and, on a symbolic level, maintains ties with the municipal parish from which most of the members of the community are recruited. How is this symbolic relationship expressed? Members of the community participate in important religious ceremonies (such as Easter, for example) and community sympathisers who want to be baptised and undergo preparation and receive their baptism in this particular parish.

It can be said that both communities approach the clergy working within the dioceses similarly: on the one hand, the Bishop is for the most part respected; on the other hand, the structure of the dioceses (the hierarchy of power, the allocation of competencies, the way public issues are set and religion is proselytised) is considered ineffective and unresponsive to the current needs of society.

If we tried to define a common feature of the critical approach of the communities to official structures, we could probably cite the fact that the clergy is considered to be burnt-out and unable to carry out their principal mission (evangelisation). Both communities are quite critical of the Church and its activities and see it as an institution

\footnotetext{
28 'We have good relations with him [the pastor] because he is scared of people and when I've needed something I've usually "used" this (...). We told him that we wanted to mow the Church lawn - that was the first thing we wanted from him. I told him: we have animals and we have no food to give them, let us mow. Because until now, there was someone who did it who is in no way connected to the Church. We wanted the pastor to stand by us, to acknowledge that this was important for us for some reason. But it took quite a lot of time and there were a lot of things that he was reluctant about. That was in the very beginning, when we needed to settle in (...). But when he [the pastor] was supposed to take a risk or to make an unpopular decision, he usually did not support us very much. But otherwise, he is a good guy.” (Member of the Zahrada community)
} 
that (a) does not sufficiently reflect the times we live in, (b) is defensive in its relationship to majority society, (c) is unable to address relevant issues, (d) does not support viable models and projects proposed by laypeople, and (e) is stuck in the old, dysfunctional model of parishes in which laypeople support the activities carried out by priests. In other words, they see the Church as a timorous organisation with no dynamics and no strategic plan capable of taking into consideration the current state of both the Church and society. The number of priests is declining, as is the amount of energy they possess: instead of spending most of their time carrying out activities connected with evangelisation, they have to act as fundraisers to save Church-owned cultural patrimony and organise and oversee construction works; they also have to take care of multiple parishes, often ones quite far away, etc.

Communities see the source of this gloomy state of affairs as lying in the rigid and unchanged/unchangeable administrative-unit structure, in the inability of the Church to make effective use of what laypeople can offer, and in the obstinate way in which priests defend their supremacy over laypeople despite the fact that Church documents declare them as equal. Non-institutionalised lay religious communities believe that most clerics carry out activities that have no purpose and that serve more as a break, stifling other forms of faith and ways of life (both those much like practising Christians and those still trying to find their faith). Any attempt to get closer to people from this point of view is suppressed, even in cases where it is initiated by priests themselves. The result of this is the already mentioned growing distance between the Church and communities and the latter's critical view of the Church.

It must be said, however, that the clergy, too, are rather critical of the activities carried out by lay communities. The most often cited objection is that the communities spread Christian teachings in a superficial way and that faith, in their interpretation, is based on feelings (rather than being anchored in cognitive structures) ${ }^{29}{ }^{2}$ This objection reflects the ultimate question raised in a religious group: who is entitled to interpret religious facts, experiences and norms and how (Waardenburg, 1997: 12-14)? The argument about superficially transferred teachings conceals, in fact, the strongest weapon of the Church when it comes to power: the Church has control over religious acts, such as baptisms, Eucharist, confessions, etc. This, on the one hand, gives it some legitimation to its feeling of superiority, but, on the other hand, makes people see clerics as mere providers of religious services. The Church thus finds itself in a situation in which people use it in situations in which there is no other choicee, but when it comes to meeting people's needs it is unable to compete with alternative, more flexible subjects, such as NRLCs.

It can be said that, in a way, the relationship between NRLCs and the Church has been moving in circles. Church representatives expect laypeople to enter the public space and to pursue issues from the Church's long- and short-term agenda, and NRLC members represent the perfect prototype of active laypeople: they are more than willing to participate in public debates, they come up with proposals for targets and strategies for meeting them, and they are willing to publicly declare their membership in the Church. The problem, however, is that these active laypeople do not identify with the implicit idea of their being turned into passive recipients of issues and agendas determined by the Church; they are unwilling to become mere instruments of the Church's objectives. Instead, NRLCs expect to be granted adequate recognition since their activities are carried out, in fact, in support of the Church. They believe they ought to be integrated into Church structures more firmly and that they should be able to serve without, however, being demoted to the role of a tool.

From the above it is clear that both communities have an ambivalent relationship towards the Church and this applies mainly to the parishes they fall under from an administrative point of view. The Garden community's relationship to its parish is a neutral one and its ties to the Church are growing looser. Even though the members of the Garden community are still practising Christians, the activities carried out by the community are less and less often connected to the Church. What's more, the community tries to mute its relationship to the Church and in a number of cases has disavowed it. It is also slowly abandoning the idea of being a religious community, having realised that its position in relation to the public is stable now that the public greatly appreciates its work with disabled people. The community's members seem to have reached the conclusion that they do not need the

\footnotetext{
29 „When I observe the people who come through this community I feel that those who had themselves baptised do not have a very deep anchor. I reckon that they do a wonderful job there, an important one. But I think that the people they work with are just not totally anchored (...) I think that what is lacking there is life with the Church (...) I feel that they have a lot of supporters there with them who had themselves baptised. And these people, when they go back home, their faith does not perish, but it is very immature. (...) But what they lack is the energy and the power of the larger community living in faith and all the things that the others live. (...) They lack meeting more often for group prayer, Holy Communion and mass.' (a priest in the diocese)
} 
Church to back their activities. The question, however, is how the Church (the Bishop and the people around him) failed to maintain patronage over a project in which it was participating (at least on a symbolic level).

The attitude of the Gofer community changed in a different way, owing to its different orientation and goals. On the one hand, the community has been striving to shed its subordination to the parish it is located in; on the other hand, it has declared its desire to remain loyal to the Church. This desire was evident, for example, when the community tried to form closer ties to the Church by inviting a priest to assume the role as spiritual supervisor for the community, monitor it from the outside and mediate potential disputes within the community. However, the priest who actually undertook this role, did so because he had personal ties with the community, not because he was assigned to the position. The supervision plan might thus be perceived more as a wish to get the Church to support the community's goals rather than as a departure from the idea of being a lay non-institutionalised community.

The fact that a priest agreed to act as a supervisor within the Gofer community proves that some priests see the idea of lay communities as a positive thing. These positive attitudes, however, stem from personal friendships. Another interesting fact is that priests who support communities or supported their founders in the 1990s are the generational peers of the communities' founders: they are now in their forties. The research found that there was a group of laypeople who converted or went through a significantly strong process of religious socialisation in the early 1990s, i.e. in the era when the Church was at the peak of its popularity and when the public listened to it.

The examples of the communities given above show that lay communities are gradually diverging from their avowed affiliation with the Church and that, metaphorically, they hover on the border between the Church and society. In such cases, they start to see themselves as islands of positive deviation. ${ }^{30}$ The reasons for the state of affairs reached in this stage are not to be found solely in the way the Church acts: another important factor are the individualisation processes that permeate the everyday life of the community to such an extent that they jeopardise the community's very existence.

\section{Conclusion}

This field study examined the position the Czech Catholic Church in the Czech Republic and non-institutionalised lay religious communities established within the frame of the Church and in response to such processes as pluralism, individualism, consumerism and instability, which give rise to a growing sense of uncertainty. The focus hereing has been ontwo non-institutionalised lay religious communities (Gofer and Garden), based in western Bohemia in the Pilsen Diocese. The study produced a whole range of findings, the most important for this paper pertaining to the analysis of an adaptation strategy, i.e. the care for the ill strategy.

The care for the ill strategy is significantly reflected in the attitudes of NLRCs to the Church. The studied communities were founded with the ambition to live in accordance with the principles of Christianity and adopt an authentic way of life in order to confront the radical forms of individualism that started influencing the Czech Republic in the beginning of 1990s. At the same time, however, the dynamics of the communities and their activism effectively help erode stereotypical views of the Church. Both communities were successful in gradually entering the public space in the regions they are based in and managed to influence the issues on the public agenda, or to frame them according to their own views. At first sight, it might seem that both communities fulfill all the expectations the Church has with respect to well-formed laypeople. This, however, is not true, and the relationship between the Church and the communities is one of ambivalence: both communities have developed a rather reserved attitude towards the Church hierarchy or individual Church representatives. Their approach to Church has been shaped more by the personalities of individual actors than by the Church's policy, which, it must be said, is not always understandable.

The second element that has influenced the attitudes of communities towards the Church is a rigorous emphasis on the authenticity of personal faith; i.e. stress is put on Christianity in practice instead of sticking to orthodox interpretations. The stress the communities put on authenticity is in keeping with the proposition that faith has

\footnotetext{
30 'I have the impression - and this impression grows stronger and stronger - that there are tonnes of people who are longing for hope and when they feel that there is hope out there, they come and start to ask just by themselves, and start to ask and look for a way to live a life filled with hope. Well, so that is what we have been trying to do on our 'island of positive deviation'. And at the same time, I have also been trying to like the clergy. I like the Church as Christ's mystical body, it is not hard for me, I am OK with that, no problem. But what really, well, almost scares me, is to come to a meeting with a priest in $* * *$ because I feel that there is such a concentration of something that has nothing to do with hope that it is virtually impossible to even breathe there. And I don't know what the reason for this is, this question ought to be answered by the brothers themselves, OK, but that's the way I feel it.' (Member of the Gofer community)
} 
become privatised and subjectivised. ${ }^{31}$ At the same time, paradoxically, the emphasis on sharing, community and experience has led to an interesting situation: privatised and individualised religiosity enhances the processes of de-privatisation.

The research also showed that the communities in question are either gradually moving away from their declared affiliation to the Church (the Garden) or occupy a position metaphorically between the domain of the Church and society. This means that in relation to their connection to the Church, they consider themselves as islands of positive deviation (Gofer). The reasons for this can be found in the way the Church behaves, but also, to a large extent, are the result of the individualisation processes that have become so pronounced in the communities that they jeopardise the existence of the communities as such, which is clear evidence of the fact that even NLRCs have been unable to avoid such pressures. By contrast, research on life in these communities has shown that some members, sympathisers, visitors or clients perceive the communities just as a short-term 'circle of warmth' (Bauman, 2010: 65). In other words, the fact that so much emphasis is put on authenticity and personal spiritual growth makes it difficult to distinguish when the actors are creating and building the community and when they are only consuming it.

The research also showed that small local communities represent, on the one hand, a dynamic element that have the ability to attract attention from the 'grey zone', i.e. people hovering on the border between mainstream society and the Church. On the other hand, they are not very stable (because of their small number of members, short tradition, and the not very well anchored rules governing the shared aspects of life, but also because they are located far away from large cities, which is where most supporters of such communities are found).

The overall conclusion can thus be: It seems that a great communication barrier (related to the mutual lack of trust) has arisen between laypeople (represented, in this paper, by NLRCs) and Church structures (on all levels and with varying intensity). If such a barrier really does exist, then it is pointless to imagine that the number of people affiliated to the Church will stop declining. Proof of the existence of such a barrier is the tension between the active members of these communities and local pastors, which has led, for example, to attempts to abandon the idea of the community being a part of the Church and a move towards existence as an independent community that no longer needs the Church. This state of affairs and its eventual persistence does not represent a very optimistic outlook when it comes to the further development of the Church in the Czech Republic.

The NRLCs were founded in response to the uncertainties of late modern society and to processes of individualisation, which are an important element of recent development in society. Paradoxically, however, the very foundation of these communities, entering a community and involvement in religious affairs are the products of individualisation. This paradox is enhanced by the fact that the communities in no way serve to weaken individualisation processes; on the contrary, they tend rather to reinforce them, because life within and the functioning of the community as a whole are, in fact, a sort of an individualisation project that has arisen out of a need for authenticity.

It therefore seems that even a religious community cannot fulfil the role of a retreat where a person can hide to avoid the risks of the late modern era. At the same time, it is becoming evident that the communities enhance the individualisation function as a potential source of the deprivatisation of the Church. However, the problem is that to now the Church has been unable to use this potential, which is proved by the fact that an entire generation of active practising laypeople has been turning away from the Church.

The adaptation strategies applied by these NLRCs were formulated with the intention to create alternative forms of being and alternative forms of life, capable of confronting the trends that characterise late modern society. Both communities, however, have gradually created forms of co-existence and a life style that have become a 'consumable experience', which helps them sustain their economic, status and social stability. What was supposed to be an alternative has ultimately become a tool of commercialisation and is subject to the same processes inherent in the late modern era as any other entity.

\section{References}

Balík, S., \& Hanuš J. (2007). Katolická cirkev v Československu 1945-1989 (Catholic Churche in the Czechoslovakia 1945-1989). Brno: CDK.

Bauman, Z. (2010). Community. Seeking Safety in an Insecure World. Cambridge: Polity Press.

\footnotetext{
${ }^{31}$ I distinguish between the privatisation of faith, which resembles more what the sociology of religion classifies as spirituality, and the individualisation of faith, which is a demonstration of subjectivisation, but does not necessarily mean a departure from institutionalised religion.
} 
Beck, U. (2007). Vynalézání politiky (The Reinvention of Politics). Prague: Slon.

Casanova, J. (1994). Public Religions in the Modern World. Chicago - London: The University of Chicago Press.

Denzin, N., \& Lincoln, Y. (2005). The Sage Handbook of Qualitative Research. Thausand Oaks - London - New Delhi: Sage.

Havelka, M. (1995). Spor o smysl českých dějin 1895 - 1938. Praha: Torst. Kodex kanonického práva (Canon Law Code). 1994. Praha: Zvon.

König, R. (1968). The Community. New York: Schrocken Books.

McLeod, H. (2007). Náboženství a lidé západní Evropy (1789-1989). (Religion and the People of Western Europe (1789-1989)). Brno: CDK.

Nettleton, S. (2006). The Sociology of Health and Illness. Cambridge: Polity

Prudký, L. (2005). Církve a sociální soudržnost v naší zemi (Church and Social Cohesion in This Country). Prague: UK FSV CESES.

Lipovetsky, G. (2003). Éra prázdnoty. Úvahy o současném individualismu (The Empty Era. Essays about Individualismu). Prague, Prostor.

Lužný D., \& Navrátilová J. (2001). Religion and Secularisation in the Czech Republic. Sociologický časopis/Czech Sociological Review, 9(1), 85-98.

Pickel, G., \& Sammet, K. (2012). Transformations of Religiosity: Religion and Religiosity in Eastern Europe 1989-2010. Wiesbaden: VS Verlag für Sozialwissenschaften.

Dokumenty II. vatikánského koncilu. (Second Vatican Council Documents). 2002. Kostelní Vydř́i: Karmelitánské nakladatelství.

Rejdák, Z. (1994). Father František Ferda. Prague: Eminent.

von Balthasar, H. U. (2004). The Laity in the Life of the Councels: The Churchs Mission in the World. San Francisko: Communip - Igantius.

Václavík, D. (2010). Náboženství a moderní česká společnost (Religion and Modern Czech Society). Praha: Grada.

Váně, J., \& Kalvas, F. (2011). The Czech Catholic Church and Problem Legitimation: From Inspiration to Personal Effort. Central European Journal of Public Policy, 5(2), 30- 49.

Waardenburg, J. (1997). Bohové z blízka. (Gods at Close Range). Brno: MU - Georgetown.

\section{(c)) EY}

This work is licensed under a Creative Commons Attribution 3.0 License. 